\title{
ORGANIC AGRICULTURAL PRODUCTION IN THE FUNCTION OF SUSTAINABLE DEVELOPMENT OF THE MUNICIPALITY OF ŠTRPCE
}

\author{
Maja Mladenović ${ }^{1}$ \\ University of Priština - Kosovska Mitrovica, Faculty of Economics, \\ Serbia \\ Radica Bojičić \\ University of Priština - Kosovska Mitrovica, Faculty of Economics, \\ Serbia
}

\begin{abstract}
Due to favourable natural conditions, the inhabitants of the municipality of Strpce were engaged in agriculture, livestock breeding and fruit growing for decades. Although to a lesser extent, interest in agriculture is still present today, with slight variations in the type of crops being grown. In recent years, there has been an expansion of raspberry growing and beekeeping, segments that have proven to be extremely profitable. The aim of this paper is to highlight the importance of agriculture in the overall sustainable economic development of the municipality of Strpce and inhabitants individually. Based on the field research, the authors will suggest improvement of this industry, especially in the field of organic production. If the predictions are true, this will be crucial for the existence and well-being of people in this region.
\end{abstract}

Key words: organic production, sustainable development, municipality of Štrpce

\section{INTRODUCTION}

Ever since the earliest times of mankind, there have been steps towards the domestication of different types of plants, as well as strong evidence of the emergence of economies dependent on domestic plants and animals. Population growth and the tendency to provide food have, over time, led to more intensive development of branches of agriculture, crop production and livestock. With the discovery of America, at the end of the 14th century, crops and animals, previously known only to the Old World, were transferred to the New World and vice versa. The trend of increasing the intensity of agricultural production has continued in contemporary conditions, but, contrary to the previous period, instead of the conventional one, the importance is now given to sustainable agriculture.

Agricultural production has always occupied an important place in the economic position and progress of a national economy. Given its importance, it is a constant focus of interest of many researchers and a topic of numerous economic studies on the process of economic growth

\footnotetext{
${ }^{1}$ maja.mladenovic@pr.ac.rs

²radica.bojicic@pr.ac.rs
}

Vol. 22, бpoj 1/2020, cmp. 1-14 
and development. The agriculture is an important driver of economic progress agree Eberhardt and Vollrath (Eberhardt, \& Vollrath 2018, p. 483), who also believe that in most developing countries nowadays, the agricultural sector represents a significant part of gross domestic product (GDP) and employment.

However, changes that are happening rapidly in contemporary conditions have not bypassed this field either. Globalization, the integrated value chain, accelerated technological and institutional innovations as well as environmental constraints have profoundly changed the context of agriculture (Byerlee et al, 2009, p. 15). Conventional methods, along with the use of chemicals in agriculture, are becoming less popular due to the negative implications for both products and humans. For these reasons, both in the world and in our country, organic production is becoming increasingly popular.

Agriculture is one of the significant factors in the economic and social development of the Republic of Serbia, as well as its identity. Given that almost half of our country is rural, it is not surprising that since ancient times it has strong agrarian roots. Considerable growth in agricultural production was recorded in the second half of the last century until the 1980s. After that period of time, due to the circumstances then, the sown areas are in stagnation, and so are the average yields. Unfortunately, such a negative trend is still present today. Many authors agree with this (Simonović et al., 2017, p. 247), who, based on the analysis of data from the last three censuses, point out that in the current economic conditions, the survival of agriculture is threatened. In support of this, we quote the data of the Republic Statistical Office, according to which in 2018 only 46,823 hectares of agricultural land, or slightly less than $2 \%$ of the total arable land were irrigated, which is $7 \%$ less than in 2017. A negative trend is also present in livestock production, which is closely related to the primary agricultural production. According to the official data, at the beginning of 2019 a dramatic number of animal resources was recorded in Serbia, a total number of 900,000 livestock, of which 350,000 were cows and heifers. The situation in Kosovo and Metohija is similar. A survey, conducted in 2018 in the municipality of Štrpce (Mladenović \& Bojičić, 2018, p. 934), confirmed that fewer people are engaged in livestock breeding, but what is even more worrying, these few livestock farmers have even fewer livestock (66\% of respondents owns only one head of livestock).

The total area of agricultural land in the municipality of Štrpce occupies $55.15 \%$ of the total area of the municipality. Pasture account for the largest share, followed by the arable land and finally the land for fruit production (Chart 1). 
Chart 1.: Structure of agricultural land in the municipality of Štrpce

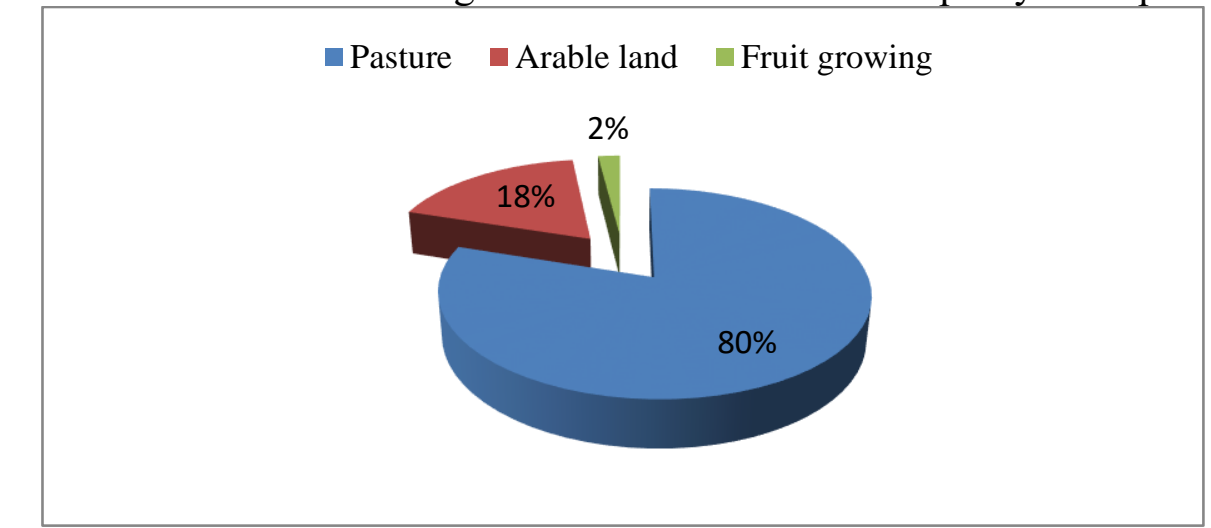

Source: Development Plan of the Municipality of Strpce, http://helvetas-ks.org/wp/wpcontent/uploads/2013/08/OP\%C5\%A0TINSKI-Razvojni-Plan-\%C5\%A0trpce.pdf

The most commonly grown crops are wheat and corn, followed by various types of fruits and vegetables, while the cultivation of medicinal herbs is in the beginning. Over the last ten years, there has been an expansion of raspberry growing, so that nowadays almost every household engaged in agriculture owns some raspberry plantations. However, in spite of all the above, the collected data from the field shows that year by year, the number of people engaged in agricultural production is slowly decreasing. Therefore, the intention of the author and one of the main goals of this paper is to present the situation in the agricultural sector in the municipality of Strpce and make suggestions for its improvement, based on the conducted research.

\section{RESEARCH METHODOLOGY}

A particular focus of this research is given to the municipality of Strpce and the current state of agricultural production in this area. Extensive analysis of existing scientific material has been carried out to determine whether agriculture in general, and organic production in particular, can be a factor of economic development and sustainable progress. The basic method used to collect the data is the direct survey method. For this purpose, the authors have created an original questionnaire with 22 questions, which, according to their opinion, best represents the state of agriculture in this municipality. In addition to the basic questions about the place of residence, gender, age, working status, income, the questionnaire also contains questions about the type of agricultural production that the inhabitants are dealing with, the use of chemicals in the production process, income, prices of agricultural 
products, the implementation of organic production and plans for the future of farmers. For the order of the answers to most of the questions asked, a five-point scale was used, with 1 rated as the least favourable or desirable answer, while 5 is rated as the affirmative or the most desirable statement. The survey included 12 villages in the municipality, i.e. a total of 101 farmers. Considering that there are no official data on the number of farmers or farms in the municipality of Strpce, according to the field data, obtained by the authors, this number ranges between 400 and 500 households.

Obtained data were processed in the IBM SPSS Statistics-version 23 software package. Due to the fact that after 1999, there are no statistical data from the Statistical Office of the Republic of Serbia for the territory of Kosovo and Metohija, and therefore for the municipality of Štrpce, the sources of the Ministries and municipalities of Štrpce functioning in the system of institutions in Priština, as well as the sources from publications of various international organizations working in this area for the last 19 years were used.

\section{RESULTS AND DISCUSSION OF THE RESEARCH}

The agricultural sector and the food sector play a very important role in the economic development of the Republic of Serbia, considering their significant share in domestic exports (Djurić et al., 2017, p. 888). The most important entities in the organization of agricultural production in Serbia are family farms, where the basic contingent of the labour force that determines the development of agriculture is concentrated (Pejanović, 2007 , p. 205). However, in the age of progress of new information technologies, genetic engineering and process automation, there are fewer of those engaged in agricultural production. According to the latest 2012 Census of Agriculture, the area of unused agricultural land in Serbia has increased. In some predominantly rural municipalities, worryingly large areas of agricultural land have been abandoned (Ševarlić, 2015, p. 6). Although this census does not cover the territory of Kosovo and Metohija, according to the authors, the downward trend is also noticeable in rural areas in Kosovo and Metohija. This is also the case with the municipality of Štrpce, in southern Kosovo and Metohija. This place, also known as Sirinićka Župa, was once proud of the fact that almost every household was engaged in some form of economic activity, while nowadays the situation is different.

Due to its favourable geographical position and climatic conditions, the conditions for agricultural development in the municipality of Štrpce are very good. Considering that the territory of the 
municipality of Štrpce is located at the altitudes of about 640 to 2,597 meters, this area, which is full of pastures, meadows and arable land, is suitable primarily for livestock breeding and then for crop and fruit production. The research, conducted for the purpose of this paper, included 101 farmers from this area, of which 54 (53.5\%) were male and $47(46.5 \%)$ were female. The survey included most of the villages in the municipality (Chart 2). Most of the respondents belong to the age group of 20-40 years (44.6\%), followed by the farmers aged 40 to 60 years $(39.6 \%)$, then those aged over 60 years $(11.9 \%)$ and finally the youngest, under 20 years of age $(4 \%)$.

Chart 2.: Place of residence of the respondents

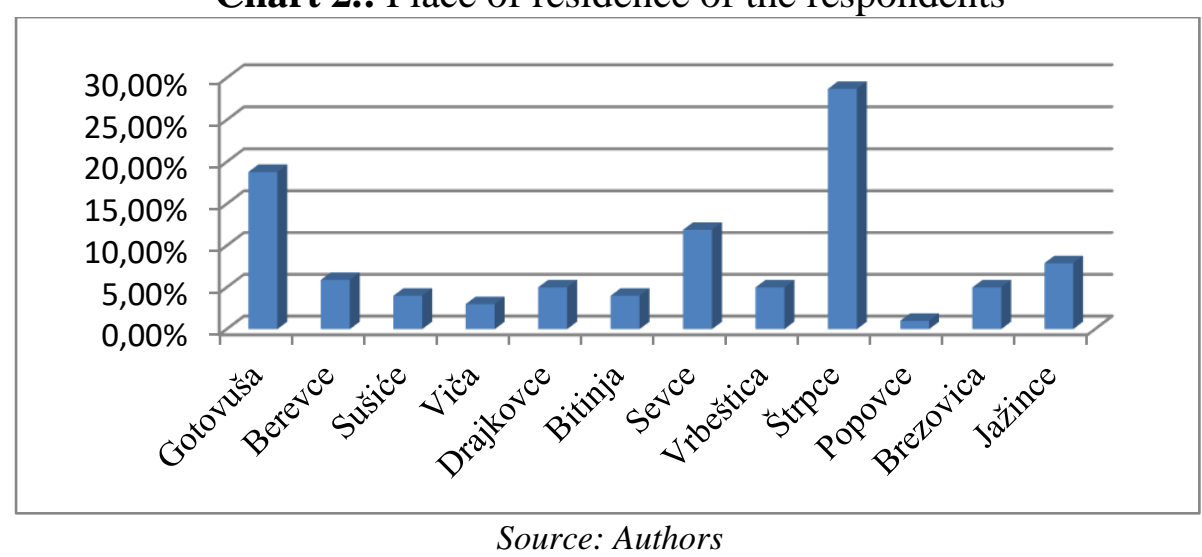

Dealing with some form of economy, crop or fruit production or livestock breeding is a tradition that has been passed down from generation to generation in many households in the municipality of Štrpce. There are families whose ancestors have been farming for hundreds of years, but there are also new family farms, who, due to lack of employment, have turned to this form of providing existence. The majority of surveyed farmers are employed (56.4\%), one third are unemployed $(30.7 \%$ ), while $12.9 \%$ are sole traders. In terms of total family income, the majority of respondents $(45.5 \%)$ have incomes over $50,000 \mathrm{RSD}$, a quarter in the range of 30-50,000 RSD, slightly less of them in the range of 10-30,000 RSD, while the lowest number $(5.9 \%)$ has incomes below 10,000 RSD. The families of our farmers, most often, have four and five members (half of them), a quarter of those surveyed stated that they live in families with six and seven members, $7 \%$ of respondents have 8 and 9 members, while $15.8 \%$ of them consist of 2 and 3 members. In the majority of families, one, two or three members are employed $(26.7,42.6 \%, 18.8 \%)$, there are also families where no one 
works $(5 \%)$, while there are fewer families of farmers where 4 or more members are employed (6.9\%).

According to the Geodetic Authority, in the municipality of Štrpce, a total of 13,649.7 hectares is used for agricultural production. Table 1 provides an overview of the areas of fertile and barren land, as well as a representation in hectares and percentages of areas for different purposes.

Table 1.: Purpose of land in the municipality of Štrpce

\begin{tabular}{|c|c|c|c|c|c|c|}
\hline Purpose & Total ha & $\begin{array}{c}\text { Total } \\
\%\end{array}$ & $\begin{array}{c}\text { Private } \\
\text { property } \\
\text { ha }\end{array}$ & $\begin{array}{l}\text { Private } \\
\text { property } \\
\%\end{array}$ & $\begin{array}{c}\text { Social } \\
\text { ownership } \\
\text { ha }\end{array}$ & $\begin{array}{c}\text { Social } \\
\text { ownership } \\
\%\end{array}$ \\
\hline Fields & $2.436,20$ & 9,94 & $2.460,70$ & 32,58 & 2,50 & 0,01 \\
\hline Gardens & 0,8 & 0 & 0,8 & 0,01 & 0 & 0 \\
\hline Orchards & 203,2 & 0,82 & 199,2 & 2,64 & 4 & 0,02 \\
\hline Vineyards & 0,3 & 0 & 0,3 & 0 & 0 & 0 \\
\hline Meadows & $3.340,70$ & 13,49 & $3.316,10$ & 43,91 & 24,60 & 0,14 \\
\hline Pastures & $7.644,50$ & 30,87 & 656,6 & 8,69 & $6.987,90$ & 40,6 \\
\hline Forest & $10.331,40$ & 41,72 & 801,1 & 10,61 & $9.530,30$ & 55,4 \\
\hline Fertile & $23.984,10$ & 96,85 & $7.434,80$ & 98,44 & $16.549,30$ & 96,2 \\
\hline Barren & 778,00 & 3,15 & 117,6 & 1,56 & 660,40 & 3,8 \\
\hline Total & $24.762,10$ & 100 & $7.552,40$ & 100 & \begin{tabular}{|l|l|}
$17.209,70$ \\
\end{tabular} & 100 \\
\hline
\end{tabular}

The municipality of Štrpce is known as the livestock area. Once, this branch of the agriculture was very profitable, while today livestock breeding farmers generally have only one head of livestock, most often for their own purposes. In recent years, entrepreneurs have increasingly turned to fruit growing, particularly raspberry growing. Experts have confirmed that the area of Sirinićka Župa is very suitable for growing raspberries and other berries, so inhabitants of this area are increasingly turning to this branch of agriculture. Fruit-growing, i.e. raspberry growing, is the branch that currently engaged the largest number of people from these areas, which is also confirmed by our research.

Since the sale of agricultural products can be very profitable, it is not surprising that the vast majority of farmers are engaged in this business for the purpose of making a profit, while there are fewer of those who cultivate certain crops for family purposes only. Serbia has the potential to produce healthy food for both domestic and export needs. As demand and costs of natural resources continue to grow in the future, driven by the growth of the world population and industrialization, it is understood that the policy of a nation, in terms of sustainable growth and development, will become increasingly important and have an increasing impact on the national economy (Mladenović \& Arsić, 2017, p. 89). 
Considering the significance given to organic products worldwide, the production of organic agricultural products can be a springboard for many smaller rural areas throughout our country if the potentials of rural places are properly used.

Chart 3.: Sample structure by agricultural branch

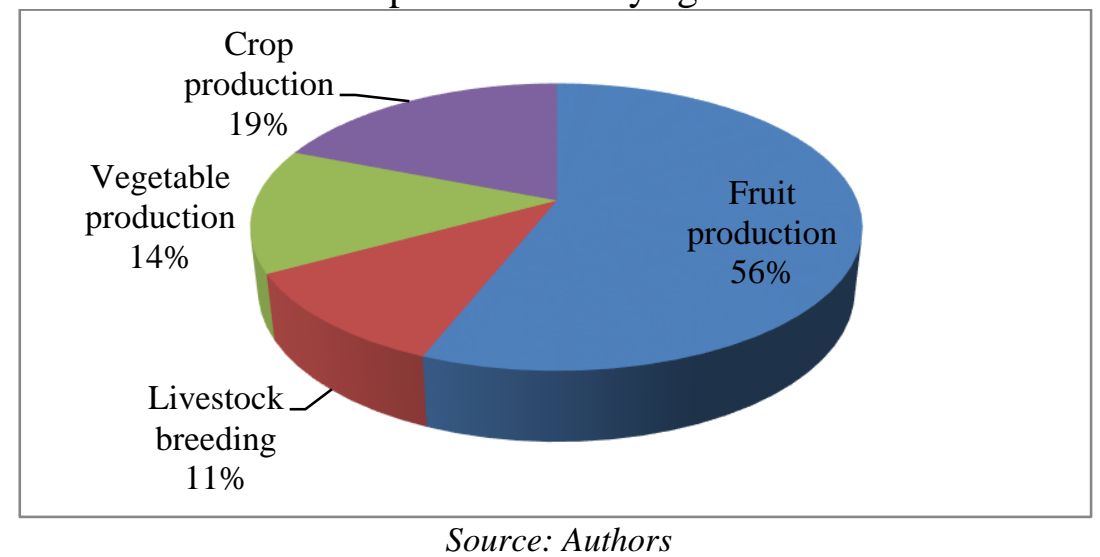

However, before farmers start with organic production, they need to be well informed about this type of production, as well as to completely put chemicals out of use. For this reason, we asked our farmers how much chemicals they use in production. Half of them $(51.5 \%)$ rarely use chemicals in production, $22.8 \%$ do on the recommendation of an expert, while only $5.9 \%$ do so very often. Still, it is encouraging that almost one fifth of respondents (19.8\%) do not use chemicals in agricultural production at all. However, despite this, many farmers are poorly informed about organic production and it's potential. Thus, $13.9 \%$ said they were poorly informed, while half of them said they had basic knowledge, which is not enough. Every third respondent $(30.7 \%)$ knows a lot about this field, while only $4 \%$ of respondents are fully informed about organic production. We were also interested in whether our respondents would use organic production in the future. A small percentage $(12.9 \%)$ were already considering starting it, a quarter of respondents said they would like to, but with the expert assistance, while a third said they would do it, not on the entire production, but on one part of it. It is worrying that close to $30 \%$ of respondents partially or completely distrust this type of production. Based on the obtained results, farmers would most often opt for organic production because of the health and better-quality nutrition of the family, but also because of higher incomes and better product placement.

The responsibility for the development and improvement of the economy and, consequently, of agricultural production in the municipality 
of Štrpce lies with everyone, starting from the locals themselves, through local self-government to the central authorities and international factors operating in these areas. Significant shortcomings in the improvement of agricultural production in the municipality of Štrpce are given in Chart 4.

Chart 4.: What is missing in order to improve agricultural production in the municipality of Štrpce?

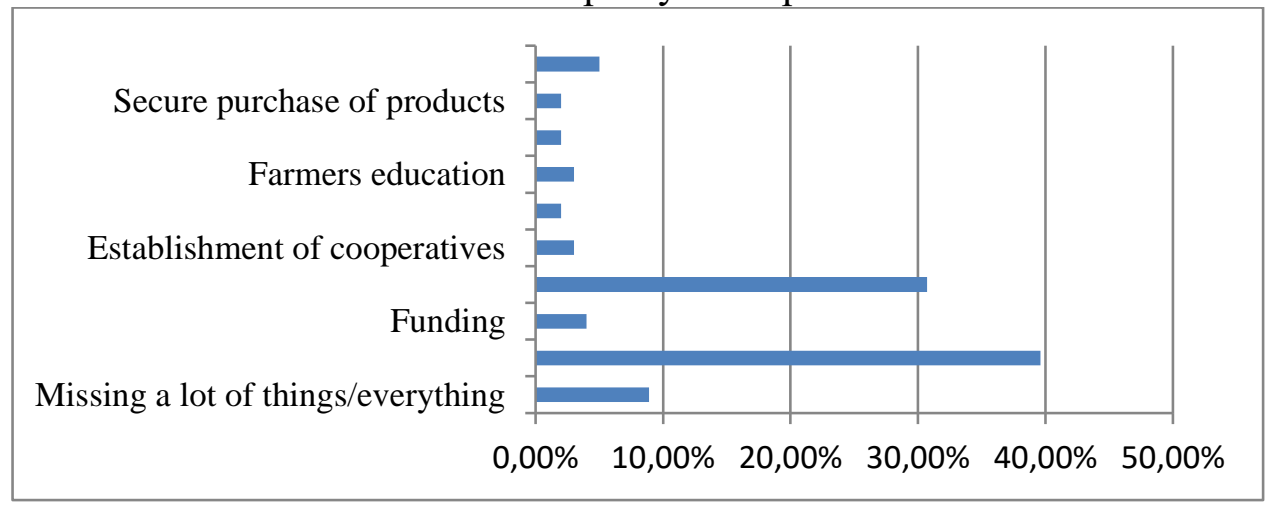

Source: Authors

Agriculture requires constant financial support because of the need to invest funds in production at once and on a large scale, in accordance with the nature of production, a long period of retention of engaged funds, that is, low turnover of invested funds, and low profit generated by the primary agricultural production, which prevents the creation of its own accumulation, that is, its own sources of financing (Zelenović et al., 2018, p. 323). Our respondents think similarly. Most of them $(39.6 \%)$ responded that assistance was needed (from local self-governments, ministries, state), while every third respondent believes that young people should, first of all, be more interested in the job. $8.9 \%$ of them think that everything is missing, 5\% say it is a modern machinery, while a smaller percentage of them states financial resources, education, mass production, cooperatives, projects and secure purchase as shortages.

Further analysis of the obtained results leads to interesting conclusions. Tradition is an inseparable part of the life of the inhabitants of the municipality of Štrpce, which is confirmed by the results of this research. Thus, the length of dealing with agricultural production depends directly on the age of the respondents, the number of family members directly influences the family's commitment to be engaged in one or more activities as well as on the decision which family member participate in the business. Also, the status of the respondents was found to be directly related to participation in the agricultural business. In addition to the above correlations, which were expected for this kind of research, there 
were some other interesting results that will allow us to have a more complete view of the overall situation in the field.

Between the variables 'place of residence' and 'type of production you are dealing with' there is a highly statistically significant relationship $(p=0.009)$ with a correlation coefficient $\rho=0.257$, which means that depending on the place of residence, the respondents initiate agricultural production that is suitable for that area. For example, all places in the municipality are very suitable for fruit growing, i.e. raspberry growing, as shown by the survey results. In every village there is at least one person engaged in fruit-growing, and in this municipality the leaders are Štrpce and Gotovuša. The situation is similar with vegetable and crop farming, while livestock production is reserved for more rural areas, with higher altitudes, such as Sevac and Jažinac. Also, a highly statistically significant relationship ( $p=0.007 ; \rho=-0.267)$ was determined between the variables 'age of the respondents' and 'how familiar are you with organic production'. A negative sign tells us that the older the farmers are, the less familiar they are with organic production, and vice versa. Lack of motivation and education, traditional habits, insufficient finances and support of younger family members result in a person becoming less interested in introducing innovations in agriculture. This is also confirmed by the highly statistically significant relationship between the variables 'respondents age' and 'whether they would apply organic production in the future' $(p=0.019 ; \rho=-0.233)$. The 'age' was also negatively correlated with the respondents' opinion on the 'existence of conditions for engaging in organic production' $(\rho=-0.246, \quad p=0.013)$. Therefore, the driver of organic production in the municipality of Strpce can hardly be found among the older population, at least not under the conditions in which they currently live. Special attention should be paid to this if a strategic plan is to be drawn up, since in this area, older farmers represent the majority.

Our research has shown that 'family income' is an important factor in dealing with any form of production, including agricultural production. Thus, the 'family income' is highly statistically correlated with the 'main motives for engaging in agricultural production' $(p=0.002 ; \rho=$ $0.310)$. The aforementioned result shows that the wealthier the families are, the more interested they are in enhancing, developing and improving production, while families with lower total incomes opt for agriculture primarily because of unemployment or the continuation of the family tradition. The amount of 'family income' also affects farmers' knowledge and awareness of organic production ( $p=0.000 ; \rho=0.327$ ), as well as the decision ' $w$ hether to use this type of production in the future' ( $p=$ $0.000 ; \rho=0.341)$. Therefore, money is one of the most important 
factors in developing awareness about the starting of organic production. Low-income households find it more difficult to opt for some innovations in business, fearing a loss, especially if all their sources of income come from agriculture.

Also, there is a statistically significant relationship between the variables 'type of work' and 'who participates in the business'. The results $(p=0.039 ; \rho=-0.205$, ) show that the harder the job, the less people are involved in the work. A proof of this is the livestock breeding, which is considered to be a hard work and for which fewer people are interested, while the interest in raspberry growing is higher because the work is less intensive and it is not done throughout the year, but only during the season. A 'job type' is also negatively correlated with the variable 'how familiar are you with organic production' ( $p=0.047 ; \rho=$ -0.198). Difficult living in the countryside, hard physical labour, especially with livestock, does not leave much time for people to research in other areas of agricultural production and introduce innovations into their work, as confirmed by the results of this research.

The 'decision to engage in organic production in the future' depends on the farmers' current habits of 'using chemicals' in production, as confirmed by this research $(p=0.025 ; \rho=-0.223)$. All those respondents, who have so far taken care of the use of chemicals in their production and kept it to a minimum, will find it easier to make a positive decision about engaging in organic production, which implies a process without the use of any chemicals. The education is one of the key factors in all fields of production, including agriculture, as shown by the highly statistically significant relationship between the 'decision to engage in organic production in the future' and the 'knowledge of organic production' ( $p=0.000 ; \rho=0.550)$.

Awareness of the 'existence of conditions for engaging in organic production' directly influences the reasons given when deciding whether to apply this type of the agricultural process $(p=0.000 ; \rho=0.464)$. The more informed the respondents are about the convenience of the conditions, the more reasons they would engage in this business in accordance with the basic principles of organic production, such as healthier and higher quality final products, but also higher revenues.

\section{CONCLUSION}

The potential for development of agricultural production of the rural areas throughout Republic of Serbia are very significant. Fruit growing, beekeeping and livestock breeding are some of the branches of agriculture whose development can drive the economic growth of rural 
places in a sustainable direction. In recent years, around the world, organic farming has been emerging as an ideal way of doing so.

Currently, $1 \%$ of the world agricultural land is organic and this percentage is on the rise (The World of Organic Agriculture - Statistics and Emerging Trends 2017, 2017, p. 25). Although legislation in this field is good, organic farms in the Republic of Serbia are still underdeveloped. Nowadays, organic farms occupy only about $0.45 \%$ of total agricultural land in Serbia (approximately 15,000 hectares), which is, compared to EU countries, relatively low (Tomaš-Simin et al., 2018, p. 265).

Fruit growing, i.e. raspberry growing, is one of the most promising branches of agriculture in the municipality of Štrpce. The research, conducted for the purpose of this paper, has shown that a large number of residents are engaged in the raspberry growing, as opposed to livestock breeding and agriculture, which are stagnating. However, despite the significant potential for organic production in the region, based on the data obtained from the field, we can conclude that much work remains to be done on the development of organic farms. This conclusion follows from the following facts:

- a large number of research participants use chemicals in their work, while fewer of them do not,

- almost half of the respondents are poorly informed about organic production and its potentials,

- one third of respondents have a complete distrust of the success of this type of production, while there is a small number of those who think about starting it.

Further analysis of the data led us to conclusions that indicate the importance of the following factors in making a decision on dealing with organic production:

- the place of residence of the farmers, which influences the decision on which branch of agriculture they will be dealing with,

- the age of the farmer, because it is directly related to the level of knowledge of organic production, as well as to their interest and willingness to start this type of production,

- family income, because the main motives for farming, the level of knowledge about organic production, but also making a decision on starting of this type of production depend on its amount,

- the type of work that farmers do, as it affects the level of knowledge about organic production and the involvement of family members in the business, 
- the use of chemicals in agricultural production, as it directly influences the awareness of the conditions and potential for dealing with organic production, as well as the decision to start this type of production.

The organic product market is growing faster than the manufacturing market and is facing many problems and challenges (Gajdić et al., 2018, p. 1461). However, despite the difficulties in implementing the basic principles of this type of production, the practice of developed market economies shows that the benefits are multiple, especially when it comes to export and incomes, which are many times higher. The more the society develops in the future, it is assumed that more of its members will strive to live healthy lives and adopt healthy habits, which will mean that demand for organic products will increase. Based on all the above, we can provide some concluding guidelines, which, in the authors' opinion, will help both farmers and decision makers along the way:

- greater assistance to farmers by the local self-government, competent authorities and institutions in terms of financial assistance, examination of conditions for organic production, projects directed towards this type of production, decisionmaking on the reduction of the use of chemicals and the like,

- education of farmers through various seminars and study visits, which will increase the awareness of the benefits and potential of organic farming,

- association of farmers as an easier way to start organic production, as well as better performance in the organic market,

- encourage young people to get more involved in organic farming, as it is concluded that the drivers of this type of production can hardly be found among the older population.

For that purpose, an idea to conduct the similar research in other areas of importance for sustainable economic development in Kosovo and Metohija occurred, since any process aimed at preserving nature while producing healthy and quality products will be significant in ensuring economic development, which is much needed for all areas inhabited by Serbs in Kosovo and Metohija. If properly steered in a sustainable direction, economic growth and development will provide a prosperous future not only for the present generations, but also for generations to come, because "today there is more than a clear need for proper and efficient management of social development" (Milačić \& Kostić, 2018, p. $10)$. 


\section{LITERATURE}

1. Byerlee, D., De Janvry, A., \& Sadoulet, E. (2009). Agriculture for Development: Toward a New Paradigm, Annual Review of Resource Economics, Vol. 1, 15-31.

2. Eberhardt, M., \& Vollrath, D. (2018). The Effect of Agricultural Technology on the Speed of Development, World Development, Vol. 109,483-496.

3. Gajdić, D., Petljak, K., \& Mesić, Ž. (2018). An exploration of distribution channels: challenges and opportunities for organic food producers in Croatia, Economic of Agriculture, 65(4), 14611482.

4. Milačić, S., \& Kostić, A. (2018). Problems of socioeconomic development in conditions of contemporary globalization. Ekonomski pogledi, 20(2), 1-16.

5. Mladenović, M. (2017). Investment and sustainable development in Štrpce municipality - possibilities and perspectives. Proceedings, International conference, IOR EDA, Faculty of Economics, Kosovska Mitrovica.

6. Mladenović, M., \& Arsić, Lj. (2017). Benefits of green economy in function increase the competitiveness of national economies, Ekonomski pogledi, 19(2), 81-97.

7. Mladenović, M., \& Bojičić, R. (2018). Production of Šar cheese development opportunity for Strpce municipality. Economic of Agriculture, 65(3), 929-942.

8. Pejanović, R. (2007). Large and Small Farms in Agriculture of the Republic of Serbia, Zbornik Matice srpske za drustvene nauke, 123, 205-218.

9. Development plan of Štrpce municipality, available at: http://helvetas-ks.org/wp/wp-

content/uploads/2013/08/OP\%C5\%A0TINSKI-Razvojni-Plan\%C5\%A0trpce.pdf accessed 25.09.2019.

10. Simonović, Z., Mihajlović, B., \& Ćurčić, N. (2017). Struktura poljoprivrednih gazdinstava prema površini poljoprivrednog zemljišta, Poslovna ekonomija, 11(2), 247-259.

11. Tomaš-Simin, M., Rodić, V., \& Glavaš-Trbić, D. (2019). Organic agriculture as an indicator of sustainable agricultural development: Serbia in focus, Economic of Agriculture, 66(1), 265-280.

12. The World of Organic Agriculture - Statistics \& Emerging Trends 2017. http://orgprints.org/34568/7/willer-lernoud-2017-02-12-v14.pdf 
13. Zelenović, V., Vojinović, Ž., \& Cvijanović, D. (2018). Serbian agriculture loans with the aim of improving the current situation, Economic of Agriculture, 65(1), 324-336.

14. Đurić, D., Ristić, J., Đurić, D., \& Vujanić, J. (2017). Export of agricultural and food products in the function of economic growth of Republic Serbia. Economic of Agriculture, 64(3), 887-900.

15. Ševarlić, M. (2015). Agricultural land, Statistical Office of Republic of Serbia. https://publikacije.stat.gov.rs/G2015/Pdf/G201514010.pdf

Рад је примьен: 22.01.2020. Коригована верзија рада је примљена: 12.05.2020.

Рад је прихваћен за штампу: 15.05.2020. 